\title{
Kajian Teologis Konsep Kebahagiaan menurut Matius 5:3
}

\author{
Yuhananik \\ Sekolah Tinggi Teologi Berita Hidup \\ yuuhananik@gmail.com
}

\begin{abstract}
Happy is the ultimate achievement that everyone in the world wants to enjoy. Various things are done to get that happiness. This article aims to provide an understanding of the concept of happiness according to Matthew 5: 3. By using the text analysis method to Matthew 5: 3, the conclusion is that it has three important meanings, namely: poor spirit, humble and dependent on God.
\end{abstract}

Keywords: Happy, Kingdom of Heaven, poor before God

Abstrak: Bahagia merupakan pencapain akhir yang ingin dinikmati oleh setiap orang di dunia. Berbagai hal dilakukan untuk mendapatkan kebahagiaan itu. Artikel ini bertujuan untuk memberikan pemahaman tentang konsep bahagia menurut Matius 5:3. Dengan menggunakan metode analisis teks terhadap Matius 5:3, didapatkan kesimpulannya memiliki tiga makna penting, yaitu: miskin roh, rendah hati dan bergantung pada Allah.

Kata kunci: berbahagia, kerajaan sorga, miskin di hadapan Allah

\section{PENDAHULUAN}

Semua orang di dunia selalu mendambakan kehidupan berbahagia. Berbagai cara ditempuh untuk meraih kebahagiaan itu. Ironisnya bahwa tidak sedikit orang yang hidupnya kelihatan mewah, glamor, populer tapi jauh dari hidup bahagia. Mengapa? Dunia kita yang materialistis ini terus menerus memburu kebahagiaan. Namun, banyak pengetahuan yang kita peroleh, semakin sedikit pula hikmat yang kita miliki. Makin besar jaminan ekonomi yang kita capai, makin besar kebosanan yang kita rasakan. Makin banyak kesenangan dunia yang kita nikmati, makin tidak puas hati kita akan kehidupan. Kita seperti laut yang tidak pernah diam, mencari sedikit damai di sini dan sekelumit kesenangan di sana, tetapi tiada yang tetap dan memuaskan kita. Oleh karena itu usaha mencari kebahagiaan itu akan terus berlangsung! Manusia akan membunuh, berdusta, berbuat curang, mencuri dan berperang untuk memusakan hasratnya akan kekuasaan, kesenangan, dan kekayaaan. Menurut anggapan mereka, apa yang dicapainya itu akan memberikan damai, sentosa, kepuasan dan kebahagiaan bagi mereka sendiri dan golongan. ${ }^{1}$

\footnotetext{
${ }^{1}$ Billy Graham, Rahasia Hidup Bahagia, LLB, Bandung, tth, 8
} 
Setiap orang sudah kehilangan kebahagiaan sejati, ketika kuasa dosa sudah hadir dan merusak segala pranata kehidupan manusia, yang diciptakan segambar dan serupa dengan Allah. Kesejahteraan dan kedamaian hidup seakan hanya menjadi sebuah impian, yang jauh dari kenyataan. Kebahagiaan yang sejati adalah kebahagiaan yang tidak pernah berubah. Ia tetap dalam segala situasi hidup, tak bergesar dan tak pernah hilang, datang dan pergi. Merasakan kenyamanan yang tak terhingga di tengah-tengah badai hidup yang paling dahsyat. Terus mengalir seperti sumber aliran sungai yang tak pernah kering, disegala musim, hujan ataupun kemarau.

Keadaan bahagia itu memang seharusnya menjadi hak setiap orang, tetapi faktanya bahwa tidak semua orang memilikinya. Walaupun kelihatannya bahagia, tetapi ternyata hatinya tidak pernah merasa bahagia, walaupun cantik, terkenal dan milioner. Karena yang kelihatan megah lahiriah, ternyata rapuh di dalamnya, hati tidak merasa nyaman dan jiwapun terasa kosong. Ada yang tak terpuaskan dengan keadaan ini, sehingga berbagai cara diupayakan untuk mencari dan berusaha mendapatkannya. Bahagia, mengapa tidak semua orang menikmatinya?

Tuhan Yesus memberi pengajaran untuk membuka rahasia hidup yang berbahagia. Khotbah-Nya di bukit memberi jalan hidup yang penuh sukacita dan bahagia. Walaupun kenyataannya bahwa konsep kebahagiaan ini tidak sama seperti yang ditawarkan oleh dunia yang penuh dengan kepalsuan. Tak terukur oleh pikiran dan akal manusiawi yang punya standar hidup bahagia berbeda, yang tidak sama dengan kebahagiaan orang-orang pada umumnya, di dunia ini. Yang disampaikan oleh Tuhan Yesus merupakan hal-hal yang sangat prinsip dan sangat serius untuk dilakukan oleh pengikut-Nya, yang akan menjalankan tugas-Nya di dunia ini. Ia ingin menyingkirkan segala penderitaan dan kekacauan hidup ini, tetap menjadi suatu kebahagiaan permanen, yang tak pernah bisa tergantikan oleh apapun.

\section{Definisi Kebahagiaan}

Kebahagiaan berasal dari kata bahagia, yang berarti suatu perasaan atau keadaan pikiran atau perasaan yang ditandai dengan kecukupan, kesenangan, cinta, kepuasan, kesenangan yang terus intens. ${ }^{2}$ Kebahagiaan yang dimaksud erat kaitannya dengan rasa sejahtera yang diukur dengan kecukupan sesuatu yang materi. Dan perasaan ini pasti hanya sebagian orang yang bisa menikmatinya, karena tidak semua orang memilikinya. Apakah untuk bahagia itu bisa memilih?

Perasaan bahagia yang dimaknai oleh suatu tindakan dan penkondisian diri untuk berbahagia. Aristoteles mengatakan bahwa "kebahagiaan itu tergantung dari diri sendiri". 3 Dalam hal ini berbahagia atau tidak merupakan suatu pilihan dari setiap pribadi, karena kebahagiaan itu relatif dan memiliki standar yang berbeda pula. Kebahagiaan itu menyangkut perasaan dan setiap perasaan yang hadir itu tidak sama. Artinya bahagia itu

\footnotetext{
${ }^{2}$ https//id.m.wikipedia.org

${ }^{3}$ Kebahagiaan menurut Aristoteles.
} 
tergantung pilihan tiap-tiap orang untuk menggapainya, jangan terpaku terlalu lama pada satu pintu yang tertutup, karena masih ada pintu lain yang terbuka untuk mendapatkannya.

Dunia yang hanya berorientasi pada materi ini tidak bisa membuahkan apa-apa, kecuali kekecewaan karena semua yang diperoleh hanya bisa memberi kepuasan sesaat. Pada saat Tuhan Yesus memberi pengajaran kepada para murid khususnya, tetapi didengar juga oleh orang banyak yang mengikuti-Nya memberi prinsip hidup bahagia yang sama sekali berbeda dengan konsep hidup manusia duniawi. Berdasarkan faktanya secara langsung Tuhan Yesus memperhadapkan kenyataan real, orang-orang yang sangat miskin; buruk keadaannya, menderita pelbagai penyakit, sengsara - kerasukan, sakit ayan, dan lumpuh (Mat. 4:23-25). Tetapi dengan kondisi ini Ia menegaskan dalam khotbah-Nya untuk tetap menjadi orang percaya yang "berbahagialah" (Mat. 5:3). Kalimat seru yang diucapkan oleh Tuhan Yesus sebagaimana hal itu memang benar-benar terjadi dan menjadi berkat bagi orang yang percaya kepada-Nya, sebagai sebuah pencapaian dan kesempurnaan akan hadirat Allah.

Dengan kondisi ini Ia menegaskan dalam khotbah-Nya bahwa para pengikut-Nya harus tetap menjadi orang-orang yang berbahagia lahir dan batin, sekalipun faktanya sangat berlawanan dan hidup jauh dari kata bahagia itu. Inilah kebahagiaan yang sejati itu, yang bersumber dari Tuhan. Penggunaan kata he makarios yang berarti bahagia, di dalam kata ini menjelaskan tentang suatu keadaan di sebuah pulau yang bernama Siprus. Pulau ini teridentifikasi sebagai pulau bahagia, karena di pulau ini terdapat keindahan, kekayaan dan kesuburan. Orang yang pergi ke pulau ini akan menemukan kehidupan yang bahagia. Kebahagiaan oleh karena ada faktor pendukung untuk perasaan bahagia, yaitu keadaan yang sangat menyenangkan.

Bahagia yang dimaksud memberi perasaan damai sejahtera yang tiada tara, yang tiada unsur duniawi. Keterkaitan antara rasa dan fakta yang sangat tidak relevan, membawa pada pemahaman kata bahagia yang sama sekali di luar nalar manusia pada umumnya. Kontradiksi dari pemikiran hidup yang hanya mengejar kenikmatan duniawi sesaat akan sulit merasakan keindahan dan kanyamanan melebihi apa yang digambarkan oleh orangorang Yunani tentang pulau Siprus. ${ }^{4}$ Tiada satupun yang bisa menyamai perasaan yang dikuasai oleh kehadiran Tuhan di dalam hati, yang tidak bisa dilukiskan atau diucapkan dengan kata-kata, karena keterikatan diri dengan kuasa dan kasih-Nya seperti yang dikatakan oleh Yakobus, “...anggaplah sebagai suatu kebahagiaan, apabila kamu jatuh dalam berbagai-bagai pencobaan" (1:2). Pernyataan ini merupakan suatu seruan kepada orang percaya untuk terus menghadirkan kerajaan sorga dalam kehidupan orang percaya yang masih di bumi ini.

Kebahagiaan yang tidak biasa, ketika segala sesuatu yang materi dan fana bukan menjadi dasar yang satu-satunya untuk menikmati rasa itu. Khotbah Tuhan Yesus di bukit memberi syarat mutlak bagi murid-murid-Nya dan pengikut-Nya meraih kebahagiaan yang

\footnotetext{
${ }^{4}$ William Barclay, Pemahaman Alkitab Setiap Hari Matius Ps 1-10. Jakarta: BPK Gunung Mulia, $1993,147$.
} 
tak ternilai ini, yang pertama adalah miskin di hadapan Allah. Ada 3 hal penting berkaitan denga makna miskin di hadapan Allah, yaitu:

\section{Miskin dalam Roh.}

Khotbah yang disampaikan oleh Tuhan Yesus memberi pengajaran kepada kita, bahwa untuk mendapatkan kebahagiaan sejati harus miskin di hadapan Allah. Kata miskin dalam bahasa inggris ditulis poor in spirit. Dan sangat jelas ditulis dalam kata Yunani adalah ptokoi. Penggunaan kata ini menjelaskan dan menegaskan pengertian yang tepat kalimat miskin di hadapan Allah, sebagai bentuk penekanan dari suatu tindakan yang harus dilakukan oleh orang percaya untuk mendapatkan kebahagiaan hidup yang sejati. Kata ptokoi menunjuk pada keadaan seseorang yang tidak memiliki apapun, bahkan untuk hidup saja harus bergantung pada pemberian orang lain. Miskin dalam roh merupakan kondisi yang sama dengan keadaan orang yang tidak berpunya, oleh karena itu orang yang miskin dalam roh bergantung sepenuhnya pada kasih karunia Allah.

Miskin dalam roh mengindikasikan bentuk penyerahan totalitas hidup dalam kuasa Roh Allah. Kepuasaan hidup terletak pada kepuasan jiwa dan roh. Kondisi ini bertolak belakang dengan orientasi hidup kedagingan yang puas dengan berbagai kenikmatan manusiawi yang tidak menyentuh kebutuhan jiwa, sehingga banyak diantaranya yang melimpah harta benda duniawi tetapi batinnya merana, sehingga akan terus menerus mencari kepuasan itu dengan berbagai cara.

Tuhan Yesus sama sekali tidak menyinggung masalah kemanusiawian kita, ketika berbicara tentang kekekalan. Apa yang sudah ditentukan Tuhan Yesus menjadi prinsip kehidupan rohani yang harus dilakukan dengan sungguh-sungguh berdasarkan pemahaman tentang etika dan moral kerajaan sorga. Memiliki disiplin tinggi dalam pengetahuan dan takut akan Tuhan, untuk terus menerus mengejar kehadiran Tuhan dalam setiap langkah hidup kita. Kemampuan untuk menjalin keakraban dengan Tuhan dalam kehidupan di dunia dengan memberikan keseluruhan hati, jiwa dan roh kepada-Nya.

Pengalaman hidup para hamba Tuhan disepanjang sejarah Perjanjian Lama dan Perjanjian Baru, yang dipanggil dan dipakai oleh Tuhan untuk melayani-Nya menjadi bukti dari penyerahan hidup yang terus menerus dipenuhi oleh Roh-Nya. Kesiapan untuk menjadi pribadi mampu menjaga relasi pribadi yang sanggup berjalan di dalam Roh-Nya, merefleksikan hidup yang hanya mengandalkan kuasa dan otoritas Tuhan semata.

Orang Kristen banyak yang mengalami kegagalan iman dan kehidupannya menjadi suam-suam kuku, seperti jemaat Laodikia (Why. 3:14-18). Mereka merasa sudah kaya dan tidak membutuhkan Tuhan lagi, tidak menyadari bahwa kekayaannya adalah kemelaratannya, kemiskinannya, kemalangannya dan kebutaanya. Ironis sekali yang dikatakan oleh Tuhan Yesus dan bahwa mereka harus membeli emas yang dimurnikan oleh Tuhan. Firman Tuhan adalah emas murni untuk membuatnya menjadi kaya rohani, sehingga terhindar dari kecongkakan diri yang berujung pada kebutaan rohani yang mematikan. Teguran Tuhan menjadi peringatan bagi gereja sebagai pribadi dan gereja 
sebagai kelompok persekutuan yang hanya mengutamakan hal-hal yang formalitas, tapi spiritualnya kerdil. Tidak ada yang bisa dibanggakan.

Pengalaman raja Saul cukup memberi “contoh hidup" yang jauh dari Roh Tuhan. Merasa diri hebat, kuat dan berpengaruh, sehingga dengan segala kesombongannya dia hidup menurut keinginannya sendiri. Karakternya sangat buruk karena tidak pernah mentaati Firman Tuhan, apalagi menjalin hubungan yang baik dengan Tuhan, yang terlihat jelas dari perilakunya yang semakin tidak mencerminkan seorang yang dekat Tuhan, yaitu: tidak menghargai hamba Tuhan, tamak, ambisius, iri dan dengki terhadap Daud. Dia menjadi raja bukan atas pilihan Allah, tetapi karena bangsa Israel yang menginginkan seorang raja karena terdesak oleh bangsa Filistin, kenyataan yang sangat situasional inilah yang membuat Samuel terpaksa mengurapinya. Ternyata jabatan seorang raja tidak mengubah perangai yang buruk, Saul semakin jahat di mata Tuhan. Itulah sebabnya Roh Allah undur darinya dan akhir hidupnya sangat tragis. Mati karena pedangnya sendiri saat bertempur dengan orang Filistin di pegunungan Gilboa.

Simson juga mengalami peristiwa yang sama, kematian yang sangat dramatis saat mengalahkan bangsa Filistin, walaupun sebenarnya Allah sudah mempersiapkan dirinya sejak dari kandungan ibunya, bahwa dia akan menjadi nazir Allah yang akan mengalahkan bangsa Filistin. Pada dasarnya apa yang dilakukan oleh Simson merupakan bagian dari skenario Allah untuk memancing reaksi bangsa Filistin atas diri Simson. Yang menjadikan Roh Allah undur dari padanya adalah Simson sudah berani berkompromi dengan dosa, mengkhianati iman dan pembaktiannya kepada Allah karena perempuan tuna susila dari lembah sorek bernama Delila. Dengan membuka rahasia kenazirannya bahwa kekuatanya karena "rambut"yang tidak boleh dicukur, atas dasar cinta buta. Saat itulah Simson tidak menyadari bahwa Roh Allah undur dari padanya sampai menjadi tawanan orang-orang Filistin dengan perlakuan yang sangat menyedihkan (Hak. 16:20).

Gambaran dua tokoh tersebut di atas dapat menjelaskan arti sesungguhnya apa arti miskin di hadapan Allah yang memiliki konotasi miskin dalam roh. Seseorang yang miskin dalam roh memiliki jalinan yang inten dengan Tuhan, ketika ada yang salah dengan sikap hatinya maka harus siap menerima konskuensinya seperti Saul dan Simson. Memelihara Firman Allah akan menjadi senjata yang sangat efektif untuk menjaga diri sendiri; untuk tidak berjalan dalam nasehat orang fasik, tidak berdiri di jalan orang berdosa dan tidak duduk dalam kumpulan pencemooh. Orang miskin dalam roh itu kesukaannya Taurat Tuhan dan merenungkannya siang dan malam. Kehidupannya terlihat seperti pohon yang ditanam di tepi aliran air, menghasilkan buah pada musimnya dan tidak layu daunnya, apa saja yang diperbuatnya berhasil (Mz. 1:1-3). Paradoks dengan kondisi orang fasik yang tidak mengenal Allah dan tidak menghidupi imannya dengan Firman Tuhan dan kasih karunia Allah, ia seperti sekam yang ditiup angin, tidak tahan dalam penghakiman dan dalam perkumpulan orang benar dan jalannya menuju kebinasaan (Mz.1:4-6).

Saulus yang ditangkap Tuhan Yesus ketika berada di Damsik memberi isyarat mutlak bagi seseorang yang akan menjadi murid Tuhan, harus miskin dalam roh (poor in spirit) 
(Kis. 9:1-19). Saulus memiliki kekuasaan yang sangat besar pengaruhnya terhadap kegiatannya sebagai penganiaya jemaat di Yerusalem, yang telah bekerja sama dengan tentara Romawi. Tuhan Yesus membuatnya buta tiga hari, supaya dia mampu melepaskan keakuannya dan kebanggaan lahiriahnya sebagai orang Farisi yang merasa tak bercacat dan sempurna. Nama Saulus harus berubah menjadi Paulus saat seluruh hidupnya diserahkankan kepada Tuhan melalui penumpangan tangan seorang hamba Tuhan yang bernama Ananias, dibabtis dan dipenuhi oleh Roh Kudus.

Perubahan besar terjadi atas pribadi Paulus yang menampilkan berbagai gaya hidup baru yang melayani Tuhan dan mempersembahkan hidupnya untuk Tuhan. Orang yang miskin dalam roh bersedia hidup dalam dalam berbagai duka cita dan kesengsaraan karenaNya, supaya kasih karunia-Nya menjadi sempurna. Terikat dalam suatu perjanjian yang tidak bisa diubah oleh apapun dan siapapun. Miskin dalam roh berkaitan erat dengan suatu kehidupan rohani yang benar-benar hancur luluh lantak tak ada daya, sebagai bentuk pengosongan diri dalam roh. Roh insani manusia, bagian yang paling dalam dari diri kita, organ yang dengannya kita bisa berkorelasi dengan Allah dan memahami hal-hal rohani.

Kita perlu menjadi miskin sama sekali, “dibongkar” kedagingan kita supaya kita bisa memahami dan mendapatkan kerajaan sorga. Ini menunjukkan bahwa kerajaan sorga itu bersifat rohani bukan material. Oleh sebab itu orang yang menyadari dirinya sebagai orang miskin di hadapan Allah, merupakan suatu kedewasaan rohani untuk mendapatkan haknya. Sangat berbahaya, jika orang yang sakit tetapi tidak menyadari bahwa dia sakit dan hampir mati. Sadar terhadap kekurangannya, kelemahannya dan kemiskinannya agar dia terus menerus dipenuhi oleh kuasa Roh Kudus.

Tuhan Yesus selalu menegur orang Farisi yang selalu merasa dirinya hebat dan rohani, yang pada kenyataannya bahwa mereka itu sangat memprihatinkan. Dengan kesombongannya selalu mengkritik pengajaran Tuhan Yesus dengan pernyataanpernyataannya teologia yang sangat dangkal, sangat menyedihkan!! Karena mereka tidak tahu kekurangannya bahkan tidak menyadari apa yang mereka lakukan. Kontras dengan miskin yang ditekankan disini adalah miskin yang menjadikan diri seperti orang yang tidak memiliki pengaruh, nista, merana dan tertindas. Tidak memiliki harta benda apa-apa atau miskin mutlak yang terpisah sama sekali dengan kekayaan duniawi.

Alasan yang sangat mendasar pada saat seseorang merasa dirinya memiliki segalanya, sesungguhnya dia tidak punya apapun, maka janganlah memegahkan diri. Bermegahlah di dalam Kristus, karena di dalam Dialah kita mendapatkan segala kepenuhan Allah untuk merasakan kepuasan hidup (Yak. 3:14). Kebahagiaan itu sama dengan kepuasan hidup, dan hanya Allah yang sanggup memuaskan hasrat manusia yang berdosa ini dengan segala kebaikan-Nya (Mz. 103:5). Dipenuhi oleh hadirat Allah merupakan suatu kebahagiaan yang tak ternilai. Yeremia menegaskan bahwa "mengenal Allah adalah kebahagiaan manusia" oleh karena itu jangan kita bermegah karena menganggap diri bijaksana, kuat dan kaya (Yer. 9:23). 
Kemampuan untuk mengatasi rasa kemanusiaan dan kedagingan merupakan wujud dari miskin dalam roh, karena tidak ada lagi pengaruh keduniawian ini yang bisa mengubah sukacita Tuhan sebagai bentuk kebahagiaan yang tak tertandingi oleh apapun di dunia ini, uang, jabatan, kekayaan atau ilmu pengetahuan. Ironis, tetapi itulah kenyataannya bahwa sulit untuk dimengerti jika sesuatu yang rohani itu menjadi kesatuan hidup yang orang yang benar-benar memahami dan mengenal Allah.

Kebebasan dari berbagai bentuk intimidasi kedagingan merupakan sebuah kebebasan yang memerdekakan orang Kristen dari segala pengaruh buruk pikiran dan tindakan dosa. Kita sekarang berada di dalam Kristus, adalah sebuah tanggung jawab untuk menyalibkan daging (Rm. 8:13), berjalan sesuai dengan Roh Kudus (Gal. 5:16), dan membiarkan pikiran kita diperbaharui (Rm. 12:2).

Tidak ada resep atau metode yang bisa mendatangkan kenyamanan hidup di tengahtengah himpitan dan tekanan jiwa seseorang. Penting untuk diketahui bahwa yang memiliki hati tentram dan damai sejahtera adalah penyerahan hidup total kepada pemilik kedamaian itu sendiri, yaitu Tuhan Yesus Kristus. Mengapa? Karena "siapa mencintai uang tidak akan puas dengan uang, dan siapa mencintai kekayaan tidak akan puas dengan penghasilannya. Ini pun sia-sia. Dengan bertambahnya harta, bertambah pula orang-orang yang menghabiskannya. Dan apakah keuntungan pemiliknya selain dari pada melihatnya" (Pkh. 5:9-10). Dengan demikian apa yang kita miliki di dunia yang serba fana ini itu tidak akan mendatangkan kebahagiaan, karena semuanya hanya sementara dan semu tidak bisa mendatangkan apa-apa, hanya sebuah kesia-siaan jika menaruh harapan dan mengejarnya.

\section{Rendah Hati}

Rendah hati memiliki konotasi yang berlawanan dengan arti tinggi hati atau sombong. Kerendahan hati disini tidak sama dengan kepentingan sendiri dan puji-pujian yang sia-sia. Kerendahan hati yang yang dikondisikan karena Kristus (Fil. 2:7, 8). Orang yang rendah hati memiliki kebahagiaan yang sempurna, karena orang yang rendah hatilah yang berhak untuk mendapatkan janji Allah, yaitu "memiliki kerajaan sorga".

Standar hidup rendah hati adalah pikiran Kristus, sebab Dia merendahkan diri-Nya sendiri adalah lanjutan dalam pengosongan diri-Nya. Tindakan Kristus merendahkan diriNya menyatakan pengosongan diri-Nya. Kematian salib adalah puncak penghinaan terhadap Kristus. Bagi orang Yahudi itu adalah kutukan (Ul. 21:22-23). Yesus sangat merendahkan diri-Nya, tetapi Allah sangat meninggikan-Nya ke puncak yang tertinggi. Penghinaan terhadap Tuhan mencakup tujuh langkah:

a.Mengosongkan diri-Nya sendiri. Rupa Allah menyiratkan realitas batiniah dari keilahian Kristus, keserupaan-Nya dengan manusia menunjukkan penampilan lahiriah dari keinsanian-Nya.

b.Mengambil rupa seorang hamba. Ia mengubah ekspresi-Nya dari rupa yang tertinggi, kepada rupa seorang hamba yang terendah.

c.Menjadi serupa dengan manusia. Rupa Kristus dalam keinsanian-Nya didapai manusia berada dalam keadaan sebagai manusia. 
d.Merendahkan diri-Nya. Tindakan Kristus merendahkan diri-Nya menyatakan bentuk pengosongan diri-Nya.

e.Menjadi taat. Kerendahan hati yang ditunjukkan dengan ketaatan-Nya.

f. Taat hingga mati. Ia sangat merendahkan diri dalam ketaatan-Nya

g. Taat hingga mati di kayu salib. ${ }^{5}$

Sikap rendah hati yang diteladankan Tuhan Yesus mengisyaratkan bahwa untuk mendapatkan suatu kenikmatan kerajaan sorga yang dibutuhkan adalah kerinduan hati terhadap hadirat Tuhan, yang terwujud dalam sikap jiwa dan roh yang benar-benar tidak "berisi" apapun (kosong). Mengikatkan diri kepada Tuhan yang mampu mengisi batin kita yang seperti tanah kering yang selalu merindukan titik air turun untuk memberi kesegaran.

Menurut B.B. Warfield: "Ia mendeklarasikan dalam ekspresi yang paling mungkin, untuk menjadi Allah sebagaimana adanya, untuk memiliki keutuhan atribut untuk menjadi Allah adalah Allah". 6 Mengarahkan pandangan hidup pada kehendak Tuhan, seperti yang dikatakan Tuhan Yesus, "Bapa biarlah cawan ini lalu dari pada-Ku, tetapi bukan kehendakKu yang jadi tetapi kehendak-Mu". Perkataan Tuhan Yesus ini memiliki makna yang sangat dalam bahwa dengan mengosongkan diri-Nya, Dia menyerahkan semua yang terjadi atas kehendak Bapa-Nya. Sikap ini menyangkut sebuah harga diri; penilaian atas dasar kualitas dan kapasitas-Nya sebagai Manusia- Allah, yang berkorelasi dengan kompetensi yang berkaitan dengan ke-Maha Kuasaan-Nya.

Tuhan Yesus melakukan dan menerima semua itu atas dasar kerelaan untuk menunjukkan kepada kita bagian terendah yang dipublikasikan kepada dunia ini, merekomendasikan sisi kerendahan hatinya untuk mencapai tujuannya, dengan tidak menganggap keseteraan-Nya dengan Allah itu sebagai milik yang harus dipertahankan, yang pada akhirnya Allah meninggikan-Nya dan mengaruniakan nama di atas segala nama.

Matius menulis syarat mutlak untuk mendapatkan kerajaan sorga adalah orang yang miskin di hadapan Allah, yang sama maknanya dengan kerendahan hati, tidak angkuh dan suka menyombongkan diri, yang menganggap diri lebih hebat dengan mengangkat harga diri berlebihan. Mengapa rendah hati? Alkitab mengajarkan tentang kehidupan yang mengutamakan pemikiran-pemikiran yang bergantung penuh sikap rendah hati sebab hanya "orang-orang yang rendah hati akan mewarisi negeri dan bergembira karena kesejahteraan yang berlimpah-limpah (Mz. 37:11).

Sikap rendah hati sangat berbanding terbalik dengan sikap sombong yang selalu agresif, menonjolkan diri sendiri. "Padahal Roh Kudus pada diriNya adalah rendah hati dan orang benar senantiasa menunjukkan kerendahan hati, keluguan dan kelemahlembutan Kristus. Perilaku khas orang yang percaya kepada Kristus adalah rendah hati dan saling merendahkan diri antara sesama mereka". 7 Mereka berperilaku demikian di dalam takut akan Kristus.

\footnotetext{
${ }^{5}$ Lembaga Alkitab Indonesia, Perjanjian Baru. Jakarta: LAI, 1997, 982-983.

${ }^{6}$ Paul Enns, Buku Pegangan Teologi Jilid 1. Malang: LLB, th, 275.

${ }^{7}$ John R.W Stott, Efesus. Jakarta: Bina Kasih/OMF, 2003, 202.
} 
Suatu kebahagiaan jika kita memiliki sikap rendah hati, karena di dalam kerendahan hati tidak akan konflik kemanusiaan, sebab tidak ada tindakan-tindakan yang mementingkan diri sendiri, yang menganggap diri lebih dari pada yang lainnya. Kerendahan hati akan mengubah persepsi tantang pribadi yang "lemah dan tak berdaya" di hadapan Tuhan, sehingga mempertajam iman dan pengharapan penuh atas anugerah Allah bagi kita, sebab itu dialah yang akan memperolah Kerajaan Sorga.

Kristus adalah pikiran kita "Hendaklah kamu dalam hidupmu bersama menaruh pikiran dan perasaan yang terdapat juga dalam Kristus Yesus" (Fil. 2:5). Pikiran Kristus yang mengajarkan tentang kerendahan hati di saat menerima penghinaan. Mengabaikan gengsi dan harga diri-Nya dan meninggalkan kemualiaan-Nya, turun ke dunia serupa dengan manusia atas kehendak-Nya sendiri.

Kerendahan hati, semangat rendah hati adalah lambang dari orang bersedia menerima panggilan untuk menerima aliran berkat-Nya. Berkat Tuhan mengalir atas orang yang menyerahkan diri, berani memikul salib, meninggalkan setiap berhala dan memegang salib dengan kuat untuk tidak berkompromi dengan keluhan-keluhan yang terus-menerus. Rasul Paulus dengan menganggap semua yang merupakan keuntungan menjadi kerugian baginya, sebagai bentuk kerendahan hati. Inilah kedaulatan yang menimbulkan hikmat dan rendah di dalam orang-orang yang merespon kehendak-Nya.

"Mengejar tujuan Allah berarti berkomitmen untuk mendengar suara-Nya bahkan ketika kita tidak sepenuhnya mengerti". ${ }^{8}$ Sikap rendah diperlukan untuk mengerjakan keselamatan yang kita terima, bagian dari bentuk respon kasih karunia untuk memelihara iman dan menyelesaikan pertandingan iman dan menjadi pemenang hingga mendapatkan janji Allah. Orang beriman selalu diperlengkapi dengan karunia Roh Kudus, yang memimpin seluruh hidup dalam kebenaran, untuk mengembangkan nilai-nilai Kekristenan dalam kehidupannya sebagai realisasi kesegambaran dan keserupaan dengan Allah (Kej. $1: 26)$.

Berita yang disampaikan oleh Matius mendorong kita untuk menjadi manusia yang rendah hati sama seperti Kristus yang rendah hati. "Alangkah jauhnya ia merendahkan diriNya, Allah- hamba- terhukum! Dari kekal sampai kekal baik di bumi atau di seluruh alam semesta inilah teladan pengorbanan diri bagi orang lain yang setinggi-tingginya"." Kemuliaan yang dikaruniakan Allah Bapa kepada Kristus merupakan hak mutlak yang diterima-Nya sebagai buah dari kerendahan hati, yang dikaruniakan atas segala bentuk kerendahan hati Kristus yang tiada taranya.

Keterbatasan pikiran kita sebagai manusia mengharuskan kita untuk hidup dalam segala kerendahan hati di hadapan Allah. Tidak ada kata yang bisa menggantikan suatu kenyataan ini, bahwa manusia berdosa ini tidak artinya sama sekali, yang hanya patut

\footnotetext{
${ }^{8}$ David Ravenhill, Mereka Minum Dari Sungai dan Mati di Padang Gurun, 2001, Jakarta: Yayasan Pekabaran Injil, 2001, 145.

${ }^{9}$ Sastro Soedirjo (penterjemah), Menggali Isi Alkitab 4 Roma sampai dengan Wahyu. Jakarta: Yayasan Bina Kasih/OMF 2002, 125.
} 
dikasihani. Orang miskin rohani menunjukkan kemiskinan yang paling memilukan, papa dan nestapa. Manusia yang telah kehilangan kemuliaan Allah (Rm. 3:23) telah gagal menggapai tujuan Allah. Semua tindakan kita telah menyimpang dari khendak Allah karena kita sering mengubahnya menurut jalan pikiran kita yang sudah tercemari kedagingan ini. Tidak ada jalan lain untuk menerima kembali janji-Nya, bahwa dengan rendah hati kita mengakui segala dosa kita.

Yesus adalah manusia seutuhnya, memiliki tubuh, jiwa dan roh. Tuhan Yesus sangat sedih akan menghadapi salib (Yoh. 12:27). Dalam roh manusia Ia sedih (Yoh. 13:21) dan sampai pada penyerahan roh-Nya (Yoh. 19:30). Dengan jalan merendahakan diri-Nyalah Ia menjadi jalan pendamaian bagi kita, ini suatu kenyataan bahwa hanya Allah yang sanggup dan yang bisa mengampuni segala dosa kita. Fakta bahwa hanya Yesus yang dapat mengampuni dosa kita adalah Ia telah mendemonstrasikan keilahian-Nya (Mrk. 2:1-12).

\section{Bergantung Pada Allah}

Manusia yang sudah jatuh ke dalam dosa sudah tidak layak mendapat bagian dalam kerajaan Sorga. Kesadaran manusia atas segala ketidak-mampuanya untuk mengentaskan diri dari perbudakan dosa dan maut, harus memperdalam rasa percaya dalam iman yang sepenuhnya bergantung kepada kasih karunia Allah. Miskin di hadapan Allah mengisyaratkan kondisi jiwa yang kosong dan tidak ada kemampuan sama sekali untuk keluar dari dosa dan segala konskuensinya. Unsur dosa yang merasuk dalam diri manusia telah menjadi "bisa" yang meracuni seluruh kehidupan manusia, racun yang mematikan! Oleh sebab itu dalam kemiskinannya, manusia membutuhkan seorang penebus yang bisa mengeluarkan dari kutuk kematian kekal.

\section{Konsep Penebusan}

Kebergantungan kita kepada Allah memiliki 3 makna dalam konsep penebusan, yaitu:

Pertama, agorazo yang berarti membeli dari pasar budak. Kata ini digunakan untuk digunakan menjabarkan orang percaya yang dibeli dari pasar dosa dan dibebaskan dari ikatan dosa. Harga pembayaran untuk kebebasan orang percaya dan pembebasan dari dosa adalah kematian Yesus Kristus (1 Kor. 6:20, 7:23). Pada saat yang bersamaan bahwa pengakuan ini, memberikan status baru kita bahwa orang percaya sudah menjadi milik Kristus, menjadi budak Kristus. Orang yang menjadi budak sudah tidak memiliki hak atas dirinya sendiri. Hidup dan mati bergantung kepada Sang pemilik. Tidak bisa lagi hidup menurut kepentingan diri sendiri, karena harganya terlalu mahal oleh sebab itu yang harus dilakukan adalah melakukan segala kehendak Allah.

Kedua, exagorazo yang berarti dikeluarkan dari pasar budak sekaligus. Kristus memerdekakan orang percaya dari ikatan hukum dan dari penghukuman (Gal. 3:13). 
Ketiga, lutroo yang artinya mendapatkan kebebasan melalui suatu pembayaran suatu harga. Tindakan Allah dalam penebusan yang direspon oleh manusia, telah memindahkan posisi manusia untuk menjadi milik Allah yang spesial (Tit. 2:14). ${ }^{10}$

Penebusan yang dilakukan oleh Allah dari sudut pandang dosa, manusia yang terikat oleh dosa dan membutuhkan pembebas untuk membebaskannya dari dosa. Rekonsiliasi untuk proses pendamaian dengan Allah sangat bergantung dari inisiatif Allah. Allah yang mencari dan menyelematkan manusia yang terhilang ini (Luk. 19:10). Berita pembebasan datang dari Allah yang telah datang ke dunia ini, memproklamirkan diri-Nya sebagai Pembebas bagi yang miskin di hadapan Allah. Rekonsiliasi inilah yang mengubah dan memperbaharui kondisi manusia yang telah hancur luluh karena dosa.

Pendamaian dan pengangkatan semua dosa manusia, berarti akhir dari keterpisahannya dengan Allah (Kpr. 13:39; Rm. 4:6-7). Hal ini juga menyangkut pembenaran atas pribadi manusia yang percaya kepada-Nya, untuk mendapatkan pelimpahan pembenaran dan mendapatkan hak atas semua yang dijanjikan pada setiap orang yang dibenarkan.

Miskin di hadapan Allah, menegaskan tentang manusia tidak bisa hidup tanpa pertolongan-Nya. Itulah sebabnya kematian Kristus merupakan bentuk penebusan yang berlaku untuk semua orang, untuk setiap orang yang miskin di hadapan Allah, yang memerlukan dan membutuhkan karya Tuhan bagi dirinya. Iman memiliki makna percaya dan mempercayakan diri. Percaya berarti berserah diri, dalam bentuk sebuah pengakuan tentang kelebihan, keunggulan, kekuatan, keagungan, kebesaran dan kemaha-kuasaan Allah di atas segala-galanya. Orang yang miskin di hadapan Allah itu mempercayakan diri, menyandarkan hidup, menyerahkan hidup, menggantungkan hidup dan segala kehidupan yang lain kepada-Nya.

Manusia telah berdosa terhadap Allah Sang Khalik yang kudus, benar dan adil. Dosa tidak diperkenankan masuk menghadap hadirat-Nya. Akibatnya dosa telah menyebabkan keterpisahan manusia dari Allah. Dan, tinggalkan dosa itu serta pelanggaran terhadap hukuk-hukum-Nya. Pengakuan yang paling jujur bahwa tanpa persekutuan dan rahmatNya, hidup kita taka da artinya, kita telah gagal dan menuju kebinasaan. Hanya orang yang bergantung kepada kepada Allah, karena Kristus sudah menebus dan menggantikannya dengan kebenaran, sukacita, kepuasan dan kebahagiaan.

\section{Iman}

Kata iman berasal dari bahasa Ibrani 'aman' yang artinya firmnes atau keteguhan, kekokohan dan ketepatan hati. Dalam bahasa Yunani 'pistis', bahasa latinya 'fides' dan dalam bahasa Inggris 'faith'. Dalam Perjanjian Lama iman artinya kesetiaan di hadapan Allah. Jadi secara hurufiah Iman berarti itu penyerahan total pada tindakan Allah. Iman merupakan sikap dan tindakan manusia untuk menerima dan mengenal Allah sebagaimana Ia dapat dikenal, seperti yang dikatakan oleh Paulus "Sebab kamu telah menerima firman

\footnotetext{
${ }^{10}$ Paul Enns, Of.Cit. hal. 401.
} 
Allah yang kami beritakan itu, bukan sebagai perkataan manusia, tetapi-dan memang sungguh-sungguh demikian-sebagai firman Allah, yang bekerja juga di dalam kamu yang percaya" (1 Tes. 2:13).

Keberadaan Tuhan tidak bisa dijangkau oleh akal budi manusia yang terbatas ini. Tuhan yang diimani oleh manusia jauh mengatasi pemikiran manusia yang berdosa ini. Manusia tidak akan mengenal-Nya hanya dengan kekuatan yang dimiliki. Iman yang kita miliki bukan karena kita mampu menjangkau-Nya, tetapi semua ketergantungan manusia kepada tindakan Allah yang telah menyatakan diri-Nya. Oleh karena itu iman selalu bermakna penyerahan diri total kepada Tuhan (Rm. 1:16). Respon manusia terhadap panggilan dan inisiatif Allah yang menyatakan diri-Nya di tengah-tengah hidup dan kehidupan manusia, merupakan bentuk realitas iman. Yang lebih utama dari semua itu adalah kesediaan dan keterlibatan manusia untuk mematuhi dan menjalankan kehendak Allah. Kualitas iman menentukan buah yang dihasilkan, atas kesediaannya dipimpim oleh Tuhan.

Yohanes menulis "Karena begitu besar kasih Alah akan dunia ini, sehingga Ia mengaruniakan anak-Nya yang tunggal, supaya setiap orang yang percaya kepada-Nya tidak binasa melainkan beroleh hidup yang kekal" (Yoh. 3:16). Sasaran kasih Allah itu universal, berlaku untuk semua umat manusia. Dalam perjanjian Baru keselamatan manusia itu bergantung penuh pada rahmat Allah di dalam Yesus Kristus. Perjanjian Baru dalam bahasa Yunani he kaine diatheke yang dibuat sebagai kesepakatan antara Allah dan manusia, dalam pengertian pesan atau wasiat terakhir, yang melibatkan dua belah pihak dan sifatnya mengikat dan tidak bisa diubah. ${ }^{11}$ Perjanjian ini sebagai wujud persetujuan baru antara Allah dan manusia melalui Kristus. Kegagalan manusia dalam menaggapi Perjanjian Lama yang orientasi keselamatan terletak pada perbuatan moralitas, ternyata taurat tidak bisa dijadikan sarana untuk keselamatan yang diharapkan oleh Allah.

Dengan memperbaharui janji-Nya Allah memberikan jalan keselamatan yang bisa direspon oleh manusia yang percaya kepada-Nya, melalui pengorbanan Tuhan Yesus di kayu Salib. Dialah jalan keselamatan itu, seperti yang dikatakan-Nya "Akulah jalan kebenaran dan hidup" (Yoh. 14:6). Dengan demikian hanya ada satu jalan menuju keselamatan, tidak ada jalan yang lainnya dan tidak ada pilihan lain. Berbahagialah setiap orang yang melalui jalan yang ditunjukkan-Nya, karena dia akan menerima rahmat-Nya.

Kecuali pemberian cuma-cuma manusia tidak bisa mendapatkan harta yang paling berharga, kerajaan sorga diberikan kepada orang miskin di hadapan Allah. Tanpa hukum taurat kebenaran itu dinyatakan dalam diri Kristus, oleh karena kasih-Nya kebenaran itu diperhitungkan sebagai akibat penebusan yang dikerjakan dalam Kristus melalui salib (Gal. 3:21-7:6) dan diberikan kepada kita, menurut pengalaman suatu kebenaran yang dikerjakan dalam hati kita oleh Roh Kudus (Gal. 7:7-8:39). ${ }^{12}$

\footnotetext{
${ }^{11}$ Yulia Bufett, Bahan ajar PB I, Karanganyar: STT Berita Hidup, 2015, 11.

${ }^{12}$ Sastro Sudirjo, 33
} 
Manusia tidak bisa memilih jalannya sendiri untuk mendapatkan keselamatan, kecuali hanya bergantung pada penetapan jalan yang dibukakan oleh Allah. Pendamaian yang Allah yang kudus, yaitu melalui korban penebusan Kristus. Dengan kematian Kristus Allah dipuaskan untuk membayar lunas dosa-dosa manusia. Darah Kristus telah memenuhi tuntutan dari kebenaran dan kekudusan Allah.

Melalui Kristus manusia memiliki pengharapan, yang bergantung pada pengenalan manusia kepada Allahnya. Pengharapan yang tergantung pada kuasa dan kehendak Allah, penyerahan diri yang melampaui batas pemikiran dan kemampuan manusia. Orang yang berbahagia di dalam Tuhan dan selalu mendapatkan pertolongan Tuhan adalah orang yang berserah dan berpengharapan. Orang yang punya harapan tidak akan kuatir tentang segala sesuatu, sebab memiliki Kristus adalah harapan terbesar, "Pengharapan itu adalah sauh yang kuat dan aman bagi jiwa kita, yang telah dilabuhkan sampai ke belakang tabir, di mana Yesus telah masuk sebagai Perintis bagi kita (Ibr. 6:19-20).

Bahagia manusia yang menaruh harapannya pada Tuhan, karena ia bisa melihat, mendengar, memahami, menyadari integritas Allah, kuasa Allah, kekuatan Allah yang melampau kemampuan manusia. Pada akhirnya manusia mampu menyandarkan dirinya pada janji-janji Allah. Inilah bentuk dari janji di atas segala kemurahan yang menyatakan segala kebaikan atas kasih Allah terhadap yang tertekan dan putus asa. Dalam Perjanjian Lama diungkapkan dengan kata ibrani "chesed" yang menekankan pertolongan atau kebaikan sebagai kemurahan dari yang lebih tinggi (Mz. 23:6; 33:18). Dalam PB dinyatakan dengan kata "charis" yaitu penyediaan keselamatan dalam Kristus (Rm. 3:24). Manusia yang miskin di hadapan Allah beroleh anugerah yang tak terhingga dari Allah, yang melampaui dosa Adam (Rm. 5:15).

\section{Kerajaan Sorga}

Yohanes Pembabtis muncul dengan pemberitaan Kerajaan Allah sudah dekat (Mat. 3:2), dan Tuhan Yesus mengambil alih perubahan ini (Mat. 4:17). Ungkapan Kerajaan Sorga dalam pengharapan Yahudi sesudah pembuangan mengandung unsur campur tangan Allah yang sungguh diharapkan Israel untuk memulihkan kebahagiaan umat-Nya dan membebaskannya dari kuasa musuh.

Kerajaan Sorga adalah istilah yang dipakai dengan khusus oleh Matius, menunjukkan bahwa kerajaan sorga adalah bagian khusus dalam kerajaan Allah, bagian yang hanya terdiri dari gereja hari ini dan bagian surgawi dari Kerajaan Seribu Tahun yang akan datang. Dalam Perjanjian Lama Kerajaan Allah umumnya sudah ada bersama dengan bangsa Israel (Mat. 21:43). Kerajaan sorga secara khusus masih belum datang dan hanya sudah dekat ketika Yohanes Pembabtis datang (Mat. 3:1-2).

Manifestasi kerajaan sorga adalah kedatangan riil kerajaan sorga dalam kuasa. Realitas dan penampilannya adalah hidup gereja yang normal (Rm. 14:17), yang berada dalam penampilan kerajaan sorga, yang dikenal sebagai kekristenan. Manifestasi kerajaan sorga adalah bagian surgawi dari Kerajaan Seribu Tahun yang akan datang. Dalam bagian Kerajaan Seribu Tahun, yaitu Kerajaan surga ternyata dalam kuasa, kaum beriman 
pemenang akan memerintah bersama Kristus selama seribu tahun (Why. 20:4,6), dalam bagian bumi kerajaan Mesias di bumi, sisa orang Israel yang beroleh selamat akan menjadi imam dan mengajar bangsa-bangsa untuk menyembah Allah (Zak. 8:20-23).

Jika kita miskin dalam roh, kerajaan sorga adalah milik kita, sekarang kita berada dalam realitasnya dalam zaman gereja, dan kita akan berbagian dalam manifestasinya dalam zaman kerajaan. ${ }^{13}$ Kemiskinan di hadapan Allah menempatkan manusia menjadi bagian dalam Kerajaan Sorga. Ketika kita membaca doa Bapa Kami dan menempatkan bersama-sama "Datanglah KerajaanMu, jadilah kehendakMu di bumi seperti di sorga"bahwa Kerajaan Allah adalah suatu masyarakat - kehendak dan kuasa Allah secara sempurna diberlakukan di dunia ini seperti di sorga.

Ketika kita menyadari kenistaan dan ketidak-mampuan untuk menjalankan hidup ini, dan apabila kita meletakkan seluruh kepercayaan dan mengandalkan diri kita kepada Allah saja, maka kerajaan sorga menjadi milik orang-orang yang miskin di hadapan-Nya. Sadar dengan ketidak-berdayaan, kelemahan dan kenistaan kita jika tanpa Allah. Sungguh berbahagia setiap orang yang mengetahui diri yang sebenarnya tidak layak, hina dan berdosa tetapi menaruh seluruh percaya dan mengandalkan diri hanya kepada Allah saja. ${ }^{14}$

Pengharapan penggenapan janji Allah untuk memperoleh Kerajaan Sorga menjadi motivasi terbesar untuk membangkitkan semangat iman Kristen pada masa penantian untuk menegakkan Kerajaan-Nya di bumi ini. Orang percaya harus setia dan terus bertekun hidup dalam Kerajaan Allah untuk menunggu Kerajaan Sorga digenapi. Yesus Kristus adalah pemimpin Kerajaan Allah yang sudah ada dari kekal sampai pada kekekalan (abadi) dan menjadi pemimpin Kerajaan Sorga. Itulah sebabnya orang yang miskin di hadapan Allah akan mendapatkan janji ini, jika mereka berusaha mengerjakan keselamatan itu dengan hanya bersandar dan beharap untuk dipenuhi dan dipuaskan dengan harta rohani, seperti sebuah bejana yang hanya puas dengan diisi air kehidupan surgawi.

Berbahagialah adalah kata yang menunjuk suatu keadaan sejahtera bagi semua orang, karena hubungannya dengan Kristus Yesus dan Firman-Nya, menerima Kerajaan Allah yang meliputi kasih, perhatian, keselamatan dan kehadiran Allah. Seseorang yang ingin menikmati Kerajaan Sorga harus bersedia dipimpin dan dituntun oleh cara dan nilai yang dinyatakan dalam Firman-Nya, yang sudah di ajarkan Tuhan Yesus di bukit "harus miskin di hadapan Allah". Dengan menyadari sepenuhnya bahwa kita tidak dapat memenuhi rohani kita sendiri, kita membutuhkan hidup, kuasa dan kasih karuniannya yang datang dari Roh Kudus untuk mewarisi Kerajaan Allah. ${ }^{15}$

Kerajaan Sorga menjadi milik orang yang miskin di hadapan Allah, yang akan dinyatakan pada saat kedatangan Tuhan Yesus, saat Israel bertobat dan janji-janji dalam Perjanjian Lama tentang pemulihan kerajaan Daud digenapi. Yesus memulai satu pemberitaan baru, memberikan perhentian dan pelayanan bagi semua orang percaya dan memprakarsai pembentukan satu keluarga iman baru tanpa memandang ras. Kerajaan

\footnotetext{
${ }^{13}$ Lembaga Alkitab Indonesia, 30.

${ }^{14}$ William Barclay, 153.

${ }^{15} \mathrm{https} / /$ alkitab.sabda.org
} 
Sorga lebih tepat dengan lingkungan orang Kristen-Yahudi, yang memelihara tradisi Injil Matius. Kenyataannya bahwa Kerajaan Allah maupun Kerajaan Sorga jarang dipakai sebelum era Yesus.

\section{KESIMPULAN}

Kebahagiaan yang diharapkan dari Matius adalah kebahagiaan yang terealisasi sangat rohani dalam kehidupan orang percaya. Kebahagiaan yang sejati, yang sama sekali tidak dipengaruhi oleh materi dan lingkungan sekitar. Kebahagiaan yang dimiliki oleh orang yang benar-benar miskin di hadapan Allah, bahwa ia, yang memiliki kesadaran penuh akan kekurangan dan kelemahannya. Orang yang berbahagia karena merasakan kasih karunia Allah yang tak terhingga, sebab dosanya tidak lagi diperhitungkan oleh Allah sebagai pembatas yang memisahkan-Nya karena kekudusan-Nya. Allah telah menebus manusia dari dosa karena rahmat-Nya. Iman yang dimiliki oleh manusia telah mengubah posisi manusia dari budak dosa menjadi orang yang dimerdekakan dari segala perbudakan dosa dan hukuman dosa, yaitu kematian jasmani dan rohani. Manusia yang tidak punya harapan telah mendapatkan kemurahan, keselamatan dan kasih yang memuaskan jiwa dan roh yang kosong, tidak berdaya. Hanya dengan sikap hati yang miskin di hadapan Allah, yang diimplementasikan dengan sikap hidup yang benar-benar: miskin dalam roh, memiliki kerendahan hati dan bergantung sepenuhnya kepada Allah.

Miskin dalam roh adalah suatu keadaan jiwa yang kosong, tanpa kejelasan harapan yang hanya terpuaskan oleh hadirat dan kasih Allah dalam Kristus. Pengorbanan-Nya adalah pendamaian bagi hati yang merindukan damai sejahtera yang melampaui segala akal pikiran (Fil. 4:7). Kerendahan hati merupakan bagian yang tak terpisahkan dari orang yang yang miskin di hadapan Allah. Sikap ini mutlak diperlukan untuk mencapai kebahagiaan yang sejati, karena orang yang rendah hati tidak suka bermegah diri dan menonjolkan diri. Ia akan menyandarkan hidupnya kepada Allah, sebagai Juru Selamat dalam segala hal, kini dan yang akan datang. Bergantung kepada Allah menjadi prinsip hidup orang percaya yang miskin di hadapan Allah. Mengakui bahwa hidup dan mati ada dalam kedaulatan Allah. Tidak ada yang bisa kita lakukan untuk mendapatkan rahmat Allah, kecuali berserah kepada karya Allah. Penebusan dosa melalui Yesus Kristus adalah jalan menuju bahagia di bumi dan di sorga. Iman kita menjadi akhir dari perjalanan pencarian hidup bahagia karena beriman kepada Yesus Kristus pemberi kebahagiaan dan damai sejahtera itu (Yoh. 14:27). Yang paling utama kebahagiaan orang percaya karena orang yang miskin di hadapan Allah itu akan memperoleh Kerajaan Sorga. Janji ini menguatkan dan membangkitkan semangat iman Kekristenan, bahwa Kerajaan Sorga menjadi bagian kita sebagai harta rohani yang paling berharga, dengan segala kuasa dan kelimpahannya (2 Kor. 4:7). 


\section{REFERENSI}

Lembaga Alkitab Indonesia, Perjanjian Baru. Jakarta: Lembaga Alkitab Indonesia, 1997. Billy Graham, Rahasia Hidup Bahagia. Bandung: Lambaga Literatur Babptis, th. David Revenhill, Mereka Minum Dari Sungai dan Mati di Padang Gurun. Jakarta:

Yayasan Pekabaran Injil, 2001.

George Eldon Ladd, Teologi Perjanjian Baru Jilid 1. Bandung: Kalam Hidup, 1999.

John R. Stott, Efesus. Jakarta: Yayasan Bina Kasih/OMF, 2003.

Paul Enns, Buku Pegangan Teologi Jilid 1. Malang: Lembaga Literatur Babtis, tth.

Sastro Soedirjo, Menggali Isi Alkitab 4 Roma Sampai Dengan Wahyu. Jakarta: Yayasan Bina Kasih/OMF, 2002.

William Barclay, Pemahaman Alkitab Setiap Hari Matius Ps 1-10. Jakarta: BPK Gunung Mulia, 1993. 